cover and investigating post-glacial features. From these studies it is concluded that the main Greenland ice sheet formerly extended into at least the south-eastern parts of Peary Land and that the major fjords (Independence Fjord, Hagen Fjord, Danmark Fjord) served as major outlets for the ice sheet. The amount of post-glacial isostatic rebound is indicated by the highest marine deposits, found at altitudes between 40 and $110 \mathrm{~m}$. A significant find of a possible interglacial sequence in south-east Peary Land may contribute to the understanding of the interglacial development in the high arctic region.

\title{
References
}

Collinson, J. D. 1979: The Proterozoic sandstones between Heilprin Land and Mylius-Erichsen Land, eastern North Greenland. Rapp. Grønlands geol. Unders. 88, 5-10.

Dawes, P. R. \& Soper, N. J. 1973: Pre-Quaternary history of North Greenland. In Pitcher, M. G. (edit.). Arctic Geology. Mem. Amer. Ass. Petrol. Geol. 19, 117-134.

Ghisler, M., Henriksen, N., Steenfelt, A. \& Stendal, H. 1979: A regional, reconnaissance, geochemical survey in the Proterozoic-Phanerozoic platform succession of the Peary Land region, North Greenland. Rapp. Grønlands geol. Unders. 88, 85-91.

Hurst, J. M. \& Surlyk, F. in press: Notes on the Lower Palaeozoic clastic sediments of Peary Land, North Greenland. Submitted to Rapp. Grønlands geol. Unders.

Jepsen, H. F. \& Kalsbeek, F. 1979: Igneous rocks in the Proterozoic platform of eastern North Greenland. Rapp. Grønlands geol. Unders. 88, 11-22.

Lane, P. D. \& Thomas, A. T. 1979: Silurian carbonate mounds in Peary Land, North Greenland. Rapp. Grønlands geol. Unders. 88, 51-54.

Pedersen, S. A. Schack 1979: Structural geology of central Peary Land, North Greenland. Rapp. Grønlands geol. Unders. 88, 55-62.

Peel, J. S. 1979: Cambrian - Middle Ordovician stratigraphy of the Adams Gletscher region, southwest Peary Land, North Greenland. Rapp. Grønlands geol. Unders. 88, 29-39.

\section{Early Cambrian microfossils from the Portfjeld Formation, Peary Land, eastern North Greenland}

\author{
John S. Peel
}

The Portfjeld Formation of eastern North Greenland is a dominantly carbonate sequence which, in its type area around Jørgen Brønlund Fjord, Peary Land, lies between the mainly clastic intervals of the Morænesø Formation, below, and the Buen Formation of early Cambrian age, above (Jepsen, 1971). In J. C. Christensen Land and Valdemar Glückstadt Land, to the east and south-east, the formation lies variously on sandstones of the Campanuladal Formation or dolomites of the Fyns Sø Formation (O'Connor, 1979). The age of the Portfjeld Formation has not previously been known with any degree of certainty, although 
its general occurrence between supposed tillites of the Morænesø Formation (Troelsen, 1956; Jepsen, 1971; Clemmensen, 1979) correlated with the Varanger sequence of Norway and the fossiliferous early Cambrian Buen Formation has caused most workers to suggest a late Precambrian - early Cambrian age. The term Eocambrian has often been applied.

Troelsen (1956) referred strata now included within the Portfjeld and Buen Formations of Jepsen (1971) to the Thule formation of North-West Greenland, the Thule Group of current usage, although this correlation is no longer accepted (Dawes, 1971, 1976). Troelsen noted the absence of fossils, other than stromatolites, and suggested an Eocambrian age. Cowie (1971) considered these beds to be of Cambrian (?) age, although no confirmatory fossil evidence was available. Jepsen (1971), in formally proposing the Portfjeld Formation, noted a sequence of about $200 \mathrm{~m}$ of mainly dolomite and suggested a Cambrian or Eocambrian age. Poulsen (1978) pointing out the lack of diagnostic fossil evidence, suggested an earliest Cambrian (partly Tommotion) age for the Portfjeld Formation on mainly physical grounds.

With the exception of stromatolites, the only previously reported fossil remains from the Portfjeld are thread-like and globular microfossils described by Pedersen $(1970,1976)$. Pedersen (1970) compared these to Eomycetopsis and Myxococcoides described from the late Precambrian of Australia by Schopf (1968) and suggested a similar late Precambrian age for the Portfjeld Formation.

In 1969 geologists of the Greenarctic Consortium collected well preserved olenellid trilobites from near the middle of the overlying Buen Formation. These were mentioned by Jepsen (1971) and subsequently described by Poulsen (1974). It thus became clear that the Portfjeld Formation could be no younger than early Cambrian, the description of the olenellids serving to confirm the record by Troelsen (1956) of olenellid fragments somewhat higher in the sequence.

In an attempt to supply more concrete evidence concerning the age of the Portfjeld Formation, a sequence of dolomite samples were collected from the formation in Wandel Dal, southern Peary Land, during field work undertaken in 1978 as part of the North Greenland 1:500 000 Mapping Project (1978-81). The approximately $1 \mathrm{~kg}$ samples were crushed, digested in dilute acetic acid and the sieved, dried residues were separated into heavy and light fractions in tetrabromoethane. Two samples, GGU 271764 and GGU 271769 , from the lower part of the formation, contained microfossils of presumed phosphatic composition in the heavy fraction.

The microfossils are parallel-sided, thin-walled tubes of uniform circular cross-section, approximately $0.05 \mathrm{~mm}$ to $0.1 \mathrm{~mm}$ in diameter. The tubes are coiled into variable helices which may have individual volutions in contact (although sometimes seemingly due to compaction) or in an open coiled, cork-screw form. The helices tend to be rather parallel-sided with an observed diameter from $0.25 \mathrm{~mm}$ to $0.5 \mathrm{~mm}$; individual fragments attain a length of over $0.5 \mathrm{~mm}$ but there is no evidence to suggest their dimensions in life. Up to four whorls have been observed.

It has not yet proved possible to assign the Portfjeld Formation microfossils to any previously described taxon. A wide range of tubular microfossils have been described from the Early Cambrian by, for example, Rozanov et al. (1969), but none of these show the coiled form typical of the Greenland specimens. The form of helical coiling employed is not gastropod-like and it is necessary at this stage to refer to the specimens as 'problematica'. Some sort of worm-like, filter-feeding mode of life is not improbable. 


\section{Age of the Portfjeld Formation}

The description of early Cambrian olenellid trilobites from the overlying Buen Formation by Poulsen (1974) has been noted above. Recent field work (Peel, 1979) has produced large early Cambrian faunas from both the Buen Formation and overlying essentially carbonate sequences of the Brønlund Fjord Group in Peary Land. A preliminary examination of this material by Palmer \& Peel (1979) indicated Bonnia-Olenellus Zone faunas of late early Cambrian age in the lower part of the Brønlund Fjord Group. The faunas of the Buen Formation could not be assigned to this zone with certainty - the presence of a nevadiid in association with the Holmia hyperborea of Poulsen (1974) suggests rather a medial early Cambrian age.

The microfossils from the Portfjeld Formation are not in themselves diagnostic as to age, other than post-Precambrian, since they have not been precisely determined. However, in view of their stratigraphic position, it is evident that most of the Portfjeld Formation is of early Cambrian age. Furthermore, the approximately $300 \mathrm{~m}$ stratigraphic interval between the microfossil yielding horizons and the medial early Cambrian trilobites of the Buen Formation may suggest that the Portfjeld Formation is partly of earliest early Cambrian (Tommotian) age. It is hoped that further microfossil search in progress will enable better control of this suggested age assignment.

\section{References}

Clemmensen, L. B. 1979: Notes on the palaeogeographic setting of the Eocambrian tillite-bearing sequence of southern Peary Land, North Greenland. Rapp. Grønlands geol. Unders. 88, 15-22.

Cowie, J. W. 1971: The Cambrian of the North American Arctic Regions. In Holland, C. H. (edit.) Cambrian of the New World, 325-383. London: Interscience.

Dawes, P. R. 1971: The North Greenland fold belt and environs. Bull. geol. Soc. Denmark 20, 197-239.

Dawes, P. R. 1976: Precambrian to Tertiary of northern Greenland. In Escher, A. \& Watt, W. S. (edit.) Geology of Greenland, 248-303. Copenhagen: Geol. Surv. Greenland.

Jepsen, H. F. 1971: The Precambrian, Eocambrian and early Palaeozoic stratigraphy of the Jørgen Brønlund Fjord area, Peary Land, North Greenland. Bull. Grønlands geol. Unders. 96 (also Meddr Grønland 192,2) 42 pp.

O'Connor, B. 1979: The Portfjeld Formation (? early Cambrian) of eastern North Greenland. Rapp. Grønlands geol. Unders. 88, 23-28.

Palmer, A. R. \& Peel, J. S. 1979: New Cambrian faunas from Peary Land, eastern North Greenland. Rapp. Grønlands geol. Unders. 91, 29-36.

Pedersen, K. R. 1970: Late Precambrian microfossils from Peary Land. Rapp. Grønlands geol. Unders. 28, 16-17.

Pedersen, K. R. 1976: Fossil floras of Greenland. In Escher, A. \& Watt, W. S. (edit.) Geology of Greenland, 518-535. Copenhagen: Geol. Surv. Greenland.

Peel, J. S. 1979: Cambrian-Middle Ordovician stratigraphy of the Adams Gletscher region, south-west Peary Land, North Greenland. Rapp. Grønlands geol. Unders. 88, 29-39.

Poulsen, V. 1974: Olenellacean trilobites from eastern North Greenland. Bull. geol. Soc. Denmark 23, $79-101$.

Poulsen, V. 1978: The Precambrian-Cambrian boundary in parts of Scandinavia and Greenland. Geol. Mag. 115, 131-136. 
Rozanov, A. Yu., Missarzhevsky, V. V;, Volkova, N. A., Voronova, L. G., Krylov, I. N., Keller, B. M., Korolyuk, I. K., Lendzion, K., Michniak, P., Pykhova, N. G. \& Sidorov, A. D. 1969: Tommotian stage and the Cambrian lower boundary problem. Trudy Geol. Inst. Akad. Nauk. SSSR 206, 380 pp. (in Russian).

Schopf, W. 1968: Microflora of the Bitter Springs formation, late Precambrian, Central Australia. J. Paleont. 42. 651-688.

Troelsen, J. C. 1956: The Cambrian of North Greenland and Ellesmere Island. In El sistema Cambrico, su paleogeografía y el problema de su base. 20 Congr. geol. inst. Mêxico. Symp. 3(1), 71-90.

\title{
Late Ordovician and early Silurian stratigraphy of Washington Land, western North Greenland
}

\author{
John S. Peel and John M. Hurst
}

This paper revises the stratigraphy of a conspicuous sequence of generally cliff-forming limestones which spans the Ordovician - Silurian boundary in Washington Land, western North Greenland (fig. 4). The strata are referred to the Morris Bugt Group, formally proposed here. Four constituent formations are recognised (fig. 5), three of which have been previously described. However, the relevant sections were originally examined by Lauge Koch under arduous conditions and the passage of more than half a century has inevitably left its mark. It is not proposed to offer a full description of all the rock units at this time. The uppermost formation, the Aleqatsiaq Fjord Formation, is described by Hurst (in press), the three older formations will be discussed fully at a later date.

The names of two of the formations, the Gonioceras Bay and Cape Calhoun Formations, are particularly well known to Ordovician stratigraphers and palaeontologists through the monographic study of their faunas by Troedsson $(1926,1928)$. However, as acknowledged by Koch (1929b), much of this material was collected from talus, so that the precise derivation of individual specimens is unknown. The present lithostratigraphic revision is a first step in an attempt to rectify this problem. The fourth formation, the Troedsson Cliff Formation, of Koch (1929a, b) has been only rarely employed since its rather uncertain proposal. However, this name is used in order to simplify some of the problems arising out of revising the often rather incomplete stratigraphy of previous workers.

A fifth formation name has previously been used, namely the Wright Bay Formation of Teichert (1937). However, the recommendations of Troelsen (1950) concerning the abandonment of this unit are followed, and the term is not employed.

The Gonioceras Bay Formation, as used here, corresponds closely to the usage of Troedsson (1928) and Koch (1929 a, b). The Troedsson Cliff Formation is enlarged from Koch's use to include part of the Cape Calhoun Formation, as defined by Troedsson and Koch. The latter formation is greatly restricted, but as a consequence becomes a much more 